\section{OPEN ACCESS}

Edited by:

Cesare Mancuso,

Catholic University of the Sacred

Heart, Italy

Reviewed by:

Jennifer Arcuri,

University of Miami Health System,

United States

Monica Baiula,

University of Bologna, Italy

*Correspondence:

Claudio Bucolo

claudio.bucolo@unict.it

${ }^{\dagger}$ These authors have contributed

equally to this work

Specialty section:

This article was submitted to

Experimental Pharmacology and Drug

Discovery,

a section of the journal

Frontiers in Pharmacology

Received: 29 November 2021

Accepted: 13 December 2021

Published: 06 January 2022

Citation:

Conti F, Lazzara F, Romano GL, Platania CBM, Drago F and Bucolo C

(2022) Caffeine Protects Against

Retinal Inflammation.

Front. Pharmacol. 12:824885.

doi: 10.3389/fphar.2021.824885

\title{
Caffeine Protects Against Retinal Inflammation
}

\author{
Federica Conti ${ }^{1 \dagger}$, Francesca Lazzara ${ }^{1 \dagger}$, Giovanni Luca Romano ${ }^{1,2}$, \\ Chiara Bianca Maria Platania ${ }^{1}$, Filippo Drago ${ }^{1,2}$ and Claudio Bucolo ${ }^{1,2 *}$
}

${ }^{1}$ Department of Biomedical and Biotechnological Sciences, School of Medicine, University of Catania, Catania, Italy, ${ }^{2}$ Center for Research in Ocular Pharmacology-CERFO, University of Catania, Catania, Italy

Caffeine, one of the most consumed central nervous system (CNS) stimulants, is an antagonist of $A_{1}$ and $A_{2 A}$ adenosine receptors. In this study, we investigated the potential protective effects of this methylxanthine in the retinal tissue. We tested caffeine by using in vitro and in vivo paradigms of retinal inflammation. Human retinal pigment epithelial cells (ARPE-19) were exposed to lipopolysaccharide (LPS) with or without caffeine. This latter was able to reduce the inflammatory response in ARPE-19 cells exposed to LPS, attenuating the release of $\mathrm{IL}-1 \beta, \mathrm{IL}-6$, and TNF- $\alpha$ and the nuclear translocation of $\mathrm{p}-\mathrm{NF} \mathrm{kB}$. Additionally, caffeine treatment restored the integrity of the ARPE-19 monolayer assessed by transepithelial electrical resistance (TEER) and the sodium fluorescein permeability test. Finally, the ischemia reperfusion (I/R) injury model was used in C57BL/6J mice to induce retinal inflammation and investigate the effects of caffeine treatment. Mouse eyes were treated topically with caffeine, and a pattern electroretinogram (PERG) was used to assess the retinal ganglion cell (RGC) function; furthermore, we evaluated the levels of IL-6 and BDNF in the retina. Retinal BDNF dropped significantly $(p<0.05)$ in the I/R group compared to the control group (normal mice); on the contrary, caffeine treatment maintained physiological levels of BDNF in the retina of $\mathrm{I} / \mathrm{R}$ eyes. Caffeine was also able to reduce IL-6 mRNA levels in the retina of I/R eyes. In conclusion, these findings suggest that caffeine is a good candidate to counteract inflammation in retinal diseases.

Keywords: caffeine, inflammation, retina, BDNF, retinal pigment epithelial cells

\section{INTRODUCTION}

Caffeine is the 1,3,7 trimethylxanthine and represents one of the most consumed central nervous system (CNS) stimulants, with an average assumption within $100-400 \mathrm{mg}$ per day (Sc and Muralidhara, 2016), through consumption of coffee, tea, and soft drinks enriched with caffeine (Mitchell et al., 2014), along with caffeine supplements, generally used as metabolism boosters (Gurley et al., 2015). Caffeine is endowed with anti-inflammatory and antioxidant properties, as reported by several studies on different models of neurodegenerative diseases, including Parkinson's disease and Alzheimer's disease (Dall'lgna et al., 2003; Carman et al., 2014; Xu et al., 2016; Hosny et al., 2019). Moreover, caffeine has shown beneficial effects in several pathologies, such as chronic stress, diabetes, attention deficit, and hyperactivity disorders (Park et al., 2007; Alves et al., 2020; Ibrahim et al., 2020). Caffeine is a non-selective adenosine receptor (AR) antagonist, although it has a higher affinity for the adenosine $A_{1}$ receptor $\left(A_{1} R\right)$ and the adenosine $A_{2 A}$ receptor $\left(A_{2 A} R\right)$; furthermore, caffeine is a non-selective inhibitor of phosphodiesterases (PDEs) (Jacobson et al., 
2020). $A_{1} R$ and $A_{2 A} R$ are G-protein-coupled receptors (GPCRs), and they are expressed in human retinal pigment epithelial (RPE) cells (Wan et al., 2011) and in other layers of the retina (Fredholm et al., 2011; Wurm et al., 2011; Liu et al., 2018).

Caffeine has provided neuroprotective action through the blockade of $\mathrm{A}_{2 \mathrm{~A}} \mathrm{R}$ (Xu et al., 2016; Boia et al., 2017). In consideration of the complex pharmacological profile of this drug, the effects of caffeine are not straightforward to be predicted (Dai and Zhou, 2011), and although the current literature provides some evidence regarding the effects of caffeine in the CNS, few studies were carried out regarding its actions in the eye. Considering the similarities between neurodegenerative diseases of the brain and retina (Romano et al., 2015, Romano et al., 2017; Platania et al., 2017), we investigated caffeine by using in vitro and in vivo paradigms of retinal inflammation. The retinal inflammatory process occurs in several ocular diseases such as age-related macular degeneration (AMD) and diabetic retinopathy (DR). This latter is one of the leading causes of irreversible vision loss in industrialized countries and represents a severe retinal degenerative disease (Van Lookeren Campagne et al., 2014). AMD is mainly characterized by accumulation of the pigment lipofuscin in the RPE cells (Katz, 2002) and by retinal ischemia (Rivera et al., 2017). About 15\% of AMD patients switch to the wet form, characterized by choroidal neovascularization. Currently, approved pharmacological treatments such as antiVEGF agents and steroids are available only for the wet form of AMD and DR (Bucolo et al., 2005; Sarao et al., 2014; Giurdanella et al., 2015; Amadio et al., 2016; Campochiaro et al., 2016; Bucolo et al., 2018); no treatments have been approved yet for the dry form of the disease where the inflammation is prevalent, and it is considered a hallmark of the early phase of this condition. Protection of RPE cells and retinal ganglion cells (RGCs), along with blood retinal barrier (BRB) preservation, can be considered as a new strategy to prevent the devastating damage of retinal degenerative diseases. It has been widely demonstrated that the activation of toll-like receptor 4 (TLR4), induced by LPS, stimulates the nuclear translocation of the nuclear factor kappa-light-chain-enhancer of activated B cells $(\mathrm{NF}-\kappa \mathrm{B})$ and, as a direct consequence, the over-expression of inflammatory cytokines, such as interleukin-6 (IL-6), interleukin$1 \beta$ (IL-1 $\beta$ ), or tumor necrosis factor-alpha (TNF- $\alpha$ ) (Holtkamp et al., 1998; Izumi-Nagai et al., 2007; Salminen and Kaarniranta, 2009; Do et al., 2020). It is noteworthy that AMD patients have increased vitreous levels of IL-1 $\beta$ (Tang and Kern, 2011; Zhao et al., 2015; Dabouz et al., 2020) and plasmatic tumor necrosis receptor 2 (TNF-R2) (Krogh Nielsen et al., 2019). Usually, RPE cells release neurotrophic factors such as the brain-derived growth factor (BDNF), which is a key factor for survival and function of RGCs and photoreceptors (Ponnalagu et al., 2017; Bahrami et al., 2019). Furthermore, low BDNF levels have been found in the aqueous humor of AMD patients, causing an insufficient protection of the retinal tissue (Inanc Tekin et al., 2018). The aim of the present study was to explore the neuroprotective and the anti-inflammatory effects of caffeine in two models of retinal inflammation by using human RPE cells and C57BL/6J mice, respectively.

\section{MATERIALS AND METHODS}

\section{Cell Culture}

Human retinal pigment epithelial cells (ARPE-19) were purchased from ATCC ${ }^{\circledast}$ (Manassas, Virginia, United States). Cells were cultured at $37^{\circ} \mathrm{C}$ (humidified atmosphere with $5 \%$ $\mathrm{CO}_{2}$ ) in ATCC-formulated DMEM:F12 medium (ATCC number 30-2006, Manassas, Virginia, United States) with $100 \mathrm{U} / \mathrm{mL}$ penicillin, $100 \mu \mathrm{g} / \mathrm{ml}$ streptomycin, and $10 \%$ fetal bovine serum (FBS). After reaching confluence ( 70\%), ARPE-19 were pretreated for $24 \mathrm{~h}$ with caffeine at concentrations of 1 , 10, 100 and $1000 \mu \mathrm{M}$ (Sigma-Aldrich, Cat.No. C0750, St Louis, MO) and/or $1 \mu \mathrm{M}$ of CGS 21680 hydrochloride (Tocris Bioscience, Cat.No. 1063, Bristol, United Kingdom) (Wang et al., 2014) in DMEM:F12 supplemented with only 5\% FBS to starve cells. In control cells (untreated), only fresh medium has been added. After pretreatment, ARPE-19 were challenged with $150 \mathrm{ng} / \mathrm{ml}, 2 \mu \mathrm{g} / \mathrm{ml}$, or $10 \mu \mathrm{g} / \mathrm{ml}$ of lipopolysaccharide E. coli (LPS) (Enzo Life Sciences ALX-581-010-L001, Farmingdale, $\mathrm{NY)}$ to simulate inflammation and also with different concentrations of caffeine $(1-100 \mu \mathrm{M})$ and/or $1 \mu \mathrm{M}$ of CGS 21680.

\section{MTT Assay}

The 3-[4,5-dimethylthiazol-2-yl]-2,5-diphenyl tetrasodium bromide (MTT; Chemicon, Temecula, CA) was used to assess cell viability. Optimal cell density was obtained by seeding $3 \times 10^{4}$ cells/well in 96-well plates (Costar, Corning, New York). After $24 \mathrm{~h}$ of culture, ARPE-19 were treated with caffeine $(1-1000 \mu \mathrm{M})$, in medium containing FBS $10 \%$ for $48 \mathrm{~h}$. At the end of the treatment, ARPE-19 were incubated at $37^{\circ} \mathrm{C}$ with MTT $(0.5 \mathrm{mg} / \mathrm{ml})$ for $2 \mathrm{~h}$; then, DMSO $100 \mu \mathrm{L}$ per well was added, and absorbance was measured at $570 \mathrm{~nm}$ in a plate reader (VariosKan, Thermo Fisher Scientific, Waltham, MA). Results were reported as the percentage of control.

\section{LDH Assay}

Lactate dehydrogenase (LDH) cell release was measured using the Cytotoxicity Detection KitPLUS (LDH) (Roche Diagnostics 04744934001, Basel, Switzerland). ARPE-19 cells were seeded at $3 \times 10^{4}$ cells/well in 96-well plates (Costar, Corning, New York). After reaching confluence, cells were treated for $48 \mathrm{~h}$ with caffeine $(1-1000 \mu \mathrm{M})$, in medium containing FBS $10 \%$. After treatment, according to the manufacturer's protocol, lysis solution was added to positive control wells (non-treated cells) for $15 \mathrm{~min}$. After transferring $100 \mu \mathrm{L}$ of the medium in a new multi-well, $100 \mu \mathrm{L}$ of the working solution was added. After 10-15 min at room temperature, $50 \mu \mathrm{L}$ of the stop solution was added lastly. The absorbance values were measured at $490 \mathrm{~nm}$ using a plate reader (VarioSkan, Thermo Fisher Scientific, Waltham, MA). LDH release is reported as $\mathrm{LDH}$ (\% control): $\left(\mathrm{abs}_{\mathrm{x}} \div\right.$ $\left.\mathrm{abs}_{\mathrm{ctrl}+}\right) \times 100$. In the equation, $\mathrm{abs}_{\mathrm{x}}$ is absorbance in the $\mathrm{x}$ well, and $a b s_{c t r l+}$ is the average absorbance of positive control cells (untreated lysed cells). Absorbance values were edited by removing the blank. 


\section{Extraction of Total RNA and cDNA Synthesis}

Extraction of total RNA, from ARPE-19 and mouse retinas, was performed with TRIzol Reagent (Invitrogen, Life Technologies, Carlsbad, CA, United States). The $\mathrm{A}_{260} / \mathrm{A}_{280}$ ratio of the optical density of RNA samples (measured with Multimode Reader Flash di Varioskan ${ }^{\mathrm{TM}}$ ) was $1.95-2.01$; this RNA purity was confirmed by electrophoresis in the non-denaturing 1\% agarose gel (in TAE). cDNA was synthesized from $2 \mu \mathrm{g}$ (ARPE-19) and $500 \mathrm{ng}$ (mice retinas) of RNA with a reverse transcription kit (SuperScript ${ }^{\mathrm{TM}}$ II Reverse transcriptase, Invitrogen, Thermo Fisher Scientific, Carlsbad, CA, United States).

\section{Real-Time Reverse Transcriptase-Polymerase Chain Reaction (RT-PCR)}

Real-time RT-PCR was carried out with the Rotor-Gene Q (Qiagen, Germantown, MD, United States). The amplification reaction mix included the Master Mix Qiagen $(10 \mu \mathrm{L})$ (Qiagen QuantiNova SYBR Green Real-Time PCR Kit, Germantown, $\mathrm{MD}$, United States) and cDNA (1 $\mu \mathrm{L}, 100 \mathrm{ng})$. Forty-five amplification cycles were carried out for each sample. Results were analyzed with the $2^{-\Delta \Delta \mathrm{Ct}}$ method (Leggio et al., 2019). Quantitative PCR experiments followed the MIQE guidelines. Gene expression levels were normalized with levels of housekeeping gene (18S). Primers were purchased from Eurofins Genomics (Milan, Italy) and Qiagen (Milan, Italy). Forward and reverse primer sequences (for human and mouse genes) and catalogue numbers are herein listed: human IL-1 $\beta$ (Forward: 5'-AGCTACGAATCTCCGACCAC-3'; Reverse: 5' CGTTATCCCATGTGTCGAAGAA-3'), human IL-6 (Catalogue Number QT00083720), human TNF- $\alpha$ (Forward 5'-AGCCCATGTTGTAGCAAACC-3'; Reverse $5^{\prime}$-TGAGGT ACAGGCCCTCTGAT-3'), human 18S (Forward $5^{\prime}$-AGTCCC TGCCCTTTG-3'; Reverse 5'-GATCCGAGGGCCTCACTA AAC-3'), human BDNF (Catalogue Number QT00235368), mice 18S (Forward: 5'-GTTCCGACCATAAACGATGCC-3'; Reverse: $5^{\prime}$-TGGTGGTGCCCTTCCGTCAAT-3'), mice BDNF (Forward: $5^{\prime}$-GTTCGAGAGGTCTGACGACG-3'; Reverse: $5^{\prime}$ AGTCCGCGTCCTTATGGTTT-3'), and mice IL-6 (Cat. No. QT00098875).

\section{Western Blot}

ARPE-19 were cultured in $60 \mathrm{~mm}$ petri dishes at a density of $1,3 \times$ $10^{6}$. After $24 \mathrm{~h}$ of pretreatment with caffeine $(1-100 \mu \mathrm{M})$ and/or CGS $21680(1 \mu \mathrm{M})$ and co-treatment with $10 \mu \mathrm{g} / \mathrm{ml}$ of LPS for $2 \mathrm{~h}$, cytoplasmic and nuclear proteins were extracted by using the CER/NER kit (NE-PER Nuclear and Cytoplasmic extraction reagents,78,833, Invitrogen, Life Technologies, Carlsbad, United States) according to the manufacturer's protocol. The protein content was determined by using the BCA Assay Kit (Pierce $^{\mathrm{TM}}$ BCA Protein Assay Kit, Invitrogen, Life Technologies, Carlsbad, United States). Extracted proteins $(20 \mu \mathrm{g})$ were loaded on the NuPAGE ${ }^{\mathrm{TM}} 10 \%$ Bis-Tris mini protein gel (Invitrogen, Life Technologies, Carlsbad, CA, United States). After electrophoresis, proteins were transferred into a nitrocellulose membrane (Invitrogen, Life Technologies, Carlsbad, CA). Membranes were blocked with milk 5\% in Tris-buffered saline $0.2 \%$ Tween 20 (TBST) for $1 \mathrm{~h}$ at room temperature. Membranes were incubated overnight $\left(4^{\circ} \mathrm{C}\right)$ with appropriate primary phospho-NFkB p65 (Ser536; mouse mAb \#3036 Cell Signaling Technology, MA, United States, 1:500 dilution), anti- $\beta$-Actin (Rabbit mAb \#A2066 Sigma-Aldrich, St Louis, MO; 1:1000 dilution), and anti-lamin B (Mouse monoclonal $\mathrm{IgG}_{2 \mathrm{~b}}$, sc365214 Santa Cruz Biotechnology, INC, CA, United States; 1: 1000 dilution) antibodies. After overnight incubation, the membranes were then incubated with secondary chemiluminescent antibodies (ECL anti-mouse, NA931 and ECL anti-rabbit, NA934, 1:2000 dilution) for $1 \mathrm{~h}$ at room temperature. After secondary antibodies, membranes were incubated with ECL (SuperSignal ${ }^{\mathrm{TM}}$ West Pico PLUS Chemiluminescent Substrate, 34,577, Thermo Fisher Scientific, Carlsbad, CA, United States) and were detected through I-Bright $^{\text {TM }} 1500$ (A43679, Invitrogen, Life Technologies, Carlsbad, CA, United States) by chemiluminescence. Densitometry analyses of blots were performed at nonsaturating exposures and analyzed by ImageJ software $(\mathrm{NIH}$, Bethesda, MD). The values were normalized to $\beta$-actin and lamin $\mathrm{B}$, which were used as housekeeping control for cytoplasmic and nuclear fraction, respectively.

\section{Transepithelial Electrical Resistance (TEER) and Permeability Test}

Transepithelial electrical resistance was measured by using a Millicell-Electrical Resistance System (ERS2) (Merck, Millipore, Burlington, MA, United States) as previously described (Giurdanella et al., 2017). TEER values were reported as $\omega \times \mathrm{cm}^{2}$ and were calculated as (average resistance of well-average resistance of the blank well) $\times 0.33$ (the area of the membrane). ARPE- 19 cells were seeded $\left(1 \times 10^{5}\right.$ cells/well $)$ in 24 well plates on cell culture transwell inserts (Falcon ${ }^{\mathrm{TM}} 24$ well $0.4 \mu \mathrm{m}$ pore size, \#353095, Becton Dickinson Labware, Bedford, MA, United States). After reaching confluence, cells were pretreated with caffeine $(1-100 \mu \mathrm{M})$ for $24 \mathrm{~h}$ in DMEM:F12 supplemented with 5\% FBS and next with LPS $2 \mu \mathrm{g} / \mathrm{ml}$ and caffeine $(1-100 \mu \mathrm{M})$ for $24 \mathrm{~h}$. To evaluate the BRB permeability, cell culture inserts were transferred in new 24well plates, and a solution of sodium fluorescein (Na-F) $(10 \mathrm{mg} /$ $\mathrm{ml}$ ) was added. After 5, 15, and $30 \mathrm{~min}$, the quantification of fluorescence (Na-F: excitation $480 \mathrm{~nm}$, emission $535 \mathrm{~nm}$ ) was carried out using a Varioskan Flash microplate reader (Thermo Fisher Scientific, Waltham, MA, United States). Values were reported as previously described (Fresta et al., 2020).

\section{Immunocytochemistry}

ARPE- 19 cells were seeded at a density of $7 \times 10^{4} /$ well on 24 -well glass chamber slides. After 3 days, cells were pretreated with caffeine $(1-100 \mu \mathrm{M})$ for $24 \mathrm{~h}$ in DMEM F12 containing $5 \%$ of FBS. Subsequently, cells were subjected to LPS stimulus $(10 \mu \mathrm{g} /$ $\mathrm{ml}$ ) for $72 \mathrm{~h}$ and different concentrations of caffeine. At the end of the treatment, cells were fixed with acetone for $15^{\prime}$ at $-20^{\circ} \mathrm{C}$ and 
subsequently with methanol for $20^{\prime}$ at $-20^{\circ} \mathrm{C}$. After washing with PBS 1X, cells were permeabilized with Triton $0.2 \%$ for $5^{\prime}$ at $4^{\circ} \mathrm{C}$. After permeabilization, cells were incubated with the primary antibody (Rabbit anti-ZO-1, 617300, Invitrogen, Life Technologies, Carlsbad, CA, United States; $1: 100$ in triton $0.1 \%$ ) overnight at $4{ }^{\circ} \mathrm{C}$. Then, cells were washed and incubated with the secondary antibody (Goat anti-rabbit, ab96899, Abcam, Cambridge, United Kingdom; 1:300 in triton $0.1 \%$ ) for $1 \mathrm{~h}$ at room temperature in the dark. After washing again, the slides were mounted using Fluoroshield ${ }^{\mathrm{TM}}$ with DAPI (F6057-29ML Sigma-Aldrich, St Louis, MO). Images were acquired by using the Zeiss Observer Z1 microscope (Carl Zeiss Microscopy GmbH, Oberkochen, Germany). A semiquantitative evaluation of the ZO-1 expression was carried out analyzing images from slides of each condition $(n=4)$ (Ctrl, LPS, LPS + caffeine $1 \mu \mathrm{M}$, LPS + caffeine $10 \mu \mathrm{M}$, LPS + caffeine $100 \mu \mathrm{M})$. The images ( $n=4$ per group) were analyzed, and ImageJ was used for measurements of the average gray scale.

\section{Animals}

Male C57BL/6J mice (3 months of age) (Charles River Laboratories, Italy) were housed in a temperature-controlled environment with free access to food and water during a $12 \mathrm{~h}$ light-dark cycle. All animals were treated according to the Principles for the Care and Use of Animals in Ophthalmic and Vision Research approved by the Association for Research in Vision and Ophthalmology. University of Catania (Italy) Ethics Committee approval \#343.

\section{Ischemic/Reperfusion Retina Damage}

Retinal ischemia/reperfusion (I/R) has been used to induce retinal injury, as previously described in many rodent species (Osborne et al., 2004; Gustavsson et al., 2008; Ulbrich et al., 2017; Stankowska et al., 2019). Mice were anesthetized by tiletamine + zolazepam $(60 \mathrm{mg} / \mathrm{kg})$ and medetomidine $(40 \mu \mathrm{g} / \mathrm{kg})$ administered through intraperitoneal injection; moreover, $0.4 \%$ oxybuprocaine (Novesina ${ }^{\circledR}$, Laboratoires Thea, ClermontFerrand, France) has been administered topically. The animals were placed on a heating pad to prevent hypothermia during the experiment. A 32-gauge needle, connected with a reservoir containing phosphate-buffered saline, was introduced into the anterior chamber through the cornea to increase the intraocular pressure (up to $90 \mathrm{mmHg}$ ). Retinal ischemia was confirmed by the observation of blanching of the anterior segment and arteries in the eye. After $60 \mathrm{~min}$, the needle was removed to allow reperfusion. Ocular formulation of $1.9 \%$ caffeine was instilled $(10 \mu \mathrm{L}) 60 \mathrm{~min}$ before I/R and after reperfusion, twice a day for $72 \mathrm{~h}$. Mice were euthanized after $72 \mathrm{~h}$ from I/R insult, the eyes were enucleated, and the retinas were collected to assess IL- 6 and BDNF mRNA expressions.

\section{Pattern Electroretinogram (PERG)}

PERG has been used as a sensitive measure of RGC function (Chou et al., 2018). Anesthetized mice were transferred on a heating plate with the mouse superior incisor teeth hooked to a bite bar and the head gently restrained by two ear knobs. The body was kept at a constant temperature of $37{ }^{\circ} \mathrm{C}$ using a feedback-controlled heating pad (TCAT-2LV, Physitemp Instruments, Inc, Clifton, NJ, United States). Two microliters of topical balanced salt solution (BSS) were applied to prevent corneal dryness. Simultaneous recordings of PERG response from both eyes were obtained using a common subcutaneous needle in the snout (jorvec Corp, Miami, FL, United States). To obtain PERG records, visual stimuli (black-white horizontal bars generated on LED tablets) are presented independently to each eye at $10 \mathrm{~cm}$ distance $\left(56^{\circ}\right.$ vertical $\times 63^{\circ}$ horizontal field; spatial frequency, 0.05 cycles/deg; $98 \%$ contrast; $800 \mathrm{~cd} / \mathrm{sqm}$ mean luminance; left-eye reversal rate, $0.992 \mathrm{~Hz}$; right-eye reversal rate, $0.984 \mathrm{~Hz}$ ). Electrical signals recorded were averaged ( $>1,110$ epochs), and PERG responses from each eye were isolated by averaging at stimulus-specific synchrony. PERG waveforms consist of a positive wave (defined as P1) followed by a slower negative wave with a broad trough (defined as N2). Therefore, each waveform has been analyzed by measuring the peak-to-trough (P1-N2) amplitude defined as the PERG amplitude and the time-to-peak of the P1 wave defined as PERG latency (Porciatti, 2014).

\section{Statistical Analysis}

Statistical analysis was performed with GraphPad prism 7 (GraphPad software La Jolla, California). The data generated by all experiments are reported as mean $\pm \mathrm{SD}(n=4)$. One-way analysis of variance (ANOVA) was carried out, and Tukey's post hoc test was used for multiple comparisons. Differences between groups were considered statistically significant for $p$-values $<0.05$.

\section{RESULTS}

\section{Effects of Caffeine on ARPE-19 Cell Viability}

Preliminary studies were carried out to evaluate cell viability and cytotoxicity after treatment with caffeine $(1-1000 \mu \mathrm{M})$. At concentrations of $1-10$ and $100 \mu \mathrm{M}$, caffeine did not reduce cell viability compared to control cells (Figure 1A). Moreover, as shown in Figure 1B, caffeine did not increase the LDH release, compared to untreated (control) cells, whereas treatment with caffeine $1000 \mu \mathrm{M}$ led to a significant $(p<0.05)$ reduction of cell viability and to a significant $(p<0.05)$ increase of the $\mathrm{LDH}$ release (Figure 1A,B). For this reason, we excluded caffeine $1000 \mu \mathrm{M}$ for all subsequent experiments.

\section{Effects of Caffeine on Inflammatory Markers and BDNF}

Treatment with LPS $(150 \mathrm{ng} / \mathrm{ml})$ led to a significant $(p<0.05)$ increase of TNF- $\alpha$, IL- 6 , and IL- $1 \beta$ mRNA levels, compared to control cells. Caffeine, at all tested concentrations, significantly $(p<0.05)$ reduced the expression of these inflammatory cytokines, in comparison with LPS-treated cells (Figure 2A-C). Moreover, LPS treatment significantly $(p<$ 0.05) reduced the BDNF expression in ARPE-19 cells, compared to untreated cells. This effect was significantly $(p<$ $0.05)$ counteracted by caffeine as demonstrated by the BDNF 

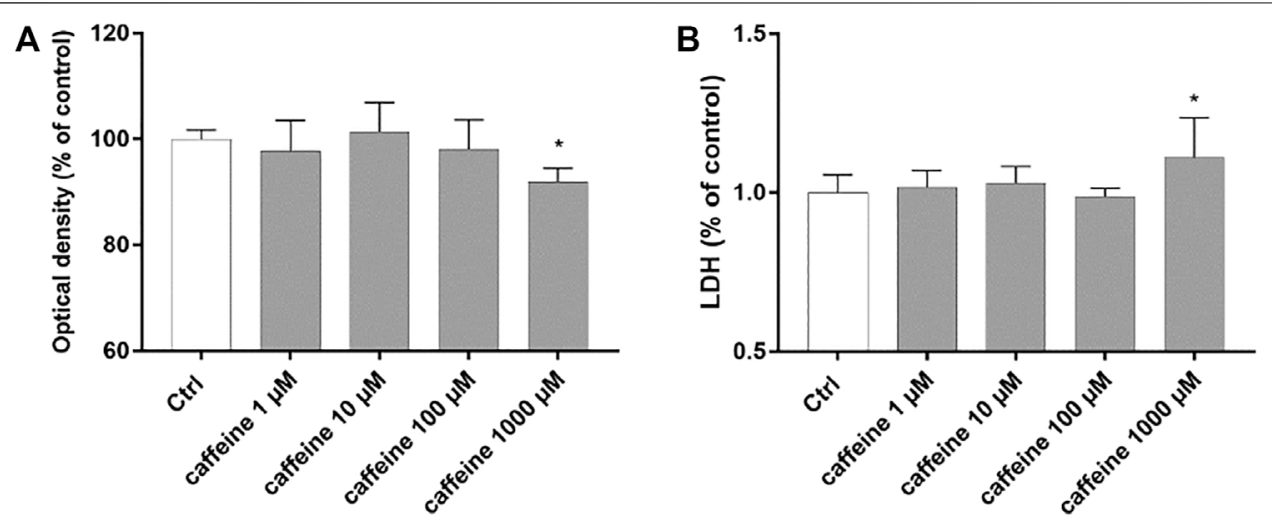

FIGURE 1 | Caffeine 1-100 $\mu \mathrm{M}$ is tolerated by ARPE-19 cells. Caffeine (1-10-100 $\mu \mathrm{M})$ after $48 \mathrm{~h}$ did not reduce cell viability (A) and did not increase LDH release (B). Values are reported as mean $\pm \mathrm{SD} ; n=4$. Data were analyzed by one-way ANOVA and the Tukey post hoc test for multiple comparisons. ${ }^{*} p<0.05$ vs. control.
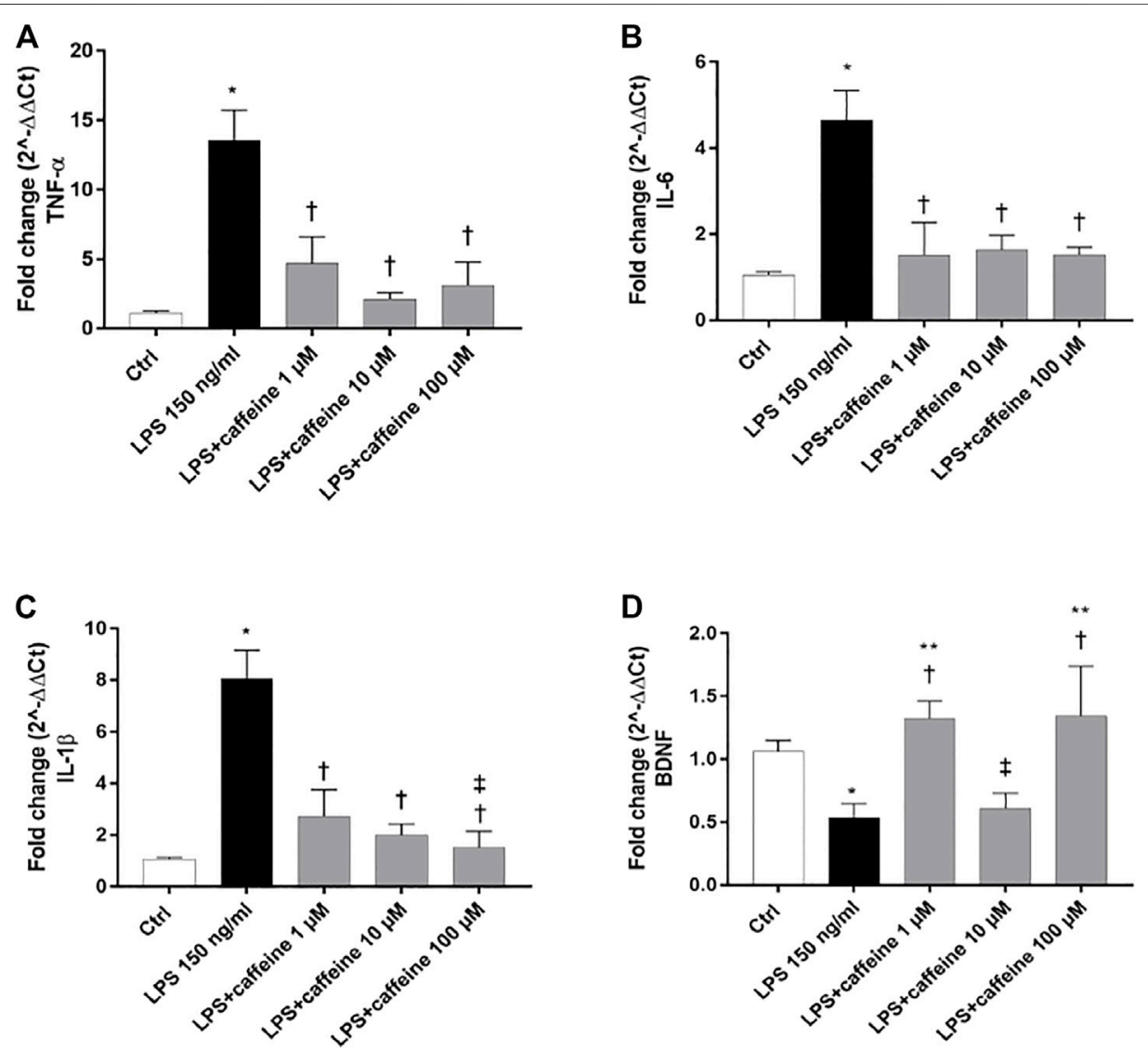

FIGURE 2 | Caffeine counteracts inflammation and elicits the BDNF expression after LPS treatment. ARPE-19 were pretreated with caffeine (1-10-100 $\mu$ M) for $24 \mathrm{~h}$ and then co-treated with LPS (150 ng/ml) for $2 \mathrm{~h}$. Caffeine downregulated TNF- $\alpha$ (A), IL-6, (B) and IL-1 13 (C) mRNA levels, up-regulated by the LPS challenge. Caffeine 1 and $100 \mu \mathrm{M}$ increased BDNF mRNA levels, reduced by LPS (D). Values were reported as mean \pm SD; $n=4$. Data were analyzed by one-way ANOVA and the Tukey post hoc test for multiple comparisons. ${ }^{*} p<0.05$ vs. control; $† p<0.05$ vs. LPS $150 \mathrm{ng} / \mathrm{ml} ;{ }^{\ddagger} p<0.05$ vs. LPS + caffeine $1 \mu \mathrm{M}$; ${ }^{* \star} p<0.05$ vs. LPS + caffeine $10 \mu \mathrm{M}$.

mRNA expression in ARPE-19 cells, damaged by LPS (Figure 2D). We found that caffeine upregulated the BDNF expression in ARPE-19 cells exposed to LPS, even though the intermediate concentration $(10 \mu \mathrm{M})$ did not have effect
(Figure 2D). Furthermore, as shown in Figure 3 (A, B, and C), the $A_{2 A}$ selective receptor agonist, CGS $21680(1 \mu \mathrm{M})$, led to a significant $(p<0.05)$ increase in mRNA levels of inflammatory cytokines, compared to cells treated with caffeine $100 \mu \mathrm{M}$. 

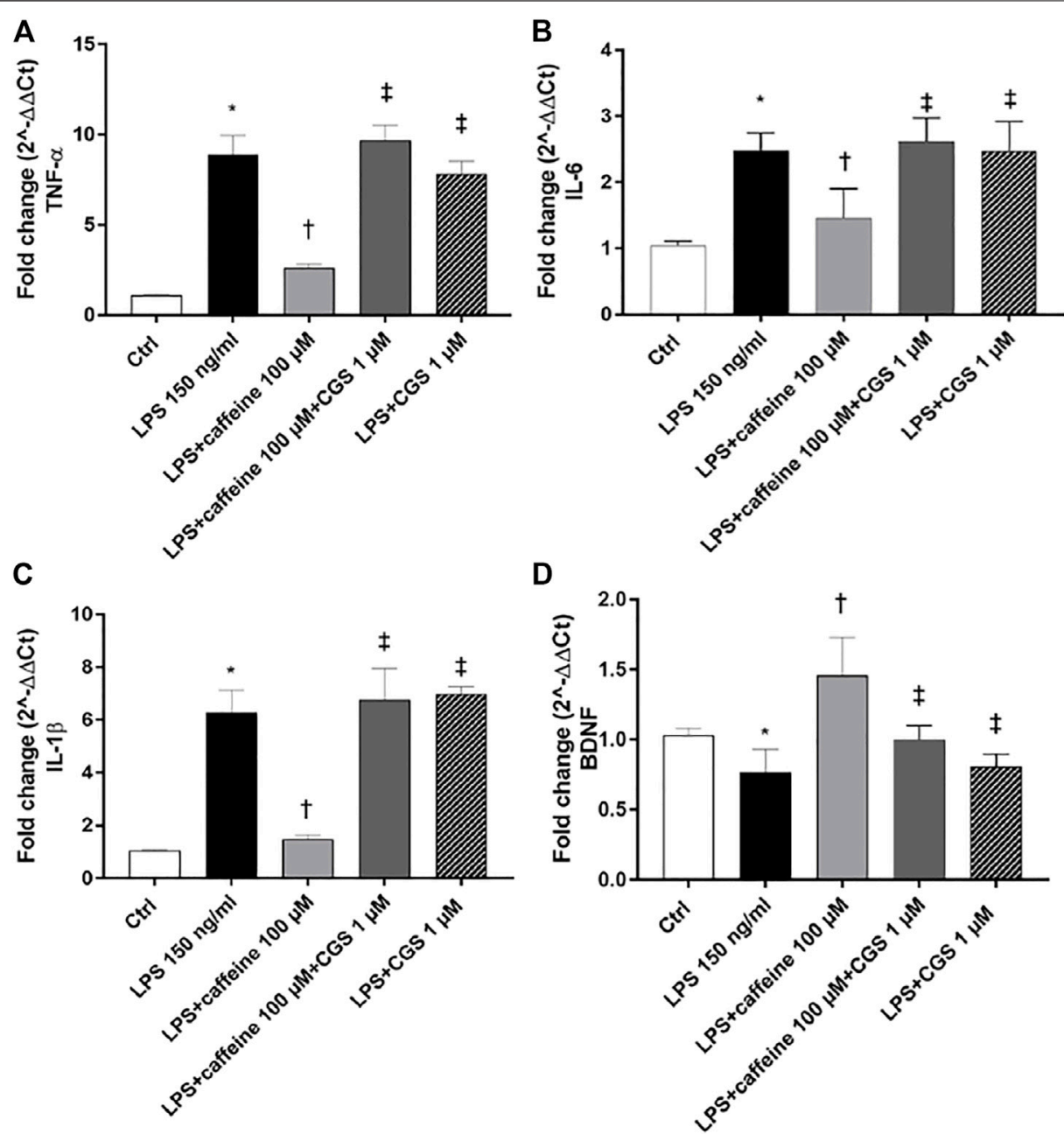

FIGURE 3| The selective $A_{2 A}$ agonist CGS 21680 counteracts the effects of caffeine. Cells were pretreated with caffeine (100 $\mu M$ ) and/or CGS ( $\left.1 \mu M\right)$ for $24 \mathrm{~h}$ and then co-treated with LPS (150 ng/ml) for $2 \mathrm{~h}$. The treatment with CGS (LPS + CGS; LPS + caffeine + CGS) did not counteract LPS-mediated effects as regard as inflammatory cytokines (A-C) or BDNF (D). Contrarily, pretreatment with caffeine (LPS + caffeine) reduced inflammatory cytokines mRNA expression and increased BDNF mRNA levels. Values are reported as mean $\pm \mathrm{SD} ; n=4$. Data were analyzed by one-way ANOVA and the Tukey post hoc test for multiple comparisons. ${ }^{*} p<0.05$ vs. control; ${ }^{\dagger} p<0.05$ vs. LPS $150 \mathrm{ng} / \mathrm{ml} ;{ }^{\ddagger} p<0.05$ vs. LPS + caffeine $100 \mu \mathrm{M}$.

Moreover, while caffeine $(100 \mu \mathrm{M})$ was able to restore significantly $(p<0.05)$ the BDNF mRNA levels, the $\mathrm{A}_{2 \mathrm{~A}}$ selective receptor agonist CGS $(1 \mu \mathrm{M})$ counteracted the effect of caffeine on the BDNF expression (Figure 3D).

\section{Effects of Caffeine on p-NFkB p65 Nuclear Translocation}

After $2 \mathrm{~h}$, LPS $(10 \mu \mathrm{g} / \mathrm{ml})$ exposure significantly $(p<0.05)$ increased the nuclear translocation of $\mathrm{p}-\mathrm{NF \kappa B}$ p 65, compared to control. Pretreatment for $24 \mathrm{~h}$ with caffeine ( 1 and $100 \mu \mathrm{M})$ significantly $(p<0.05)$ reduced the nuclear translocation of $\mathrm{p}-\mathrm{NF} \kappa \mathrm{B}$ p65, confirming the anti-inflammatory effect of this compound in retinal pigment epithelial cells, challenged with LPS. However, caffeine $10 \mu \mathrm{M}$ did not counteract the activation of NFKB (Figure 4A,B). As shown in Figure 4 (C and $D)$, the selective $A_{2 A}$ agonist CGS $(1 \mu \mathrm{M})$ counteracted the anti-inflammatory effects of caffeine on ARPE-19 cells damaged by LPS, as regards as p-NFkB p65 nuclear translocation.

\section{Effects of Caffeine on BRB Integrity}

To investigate the effect of caffeine on BRB integrity, we assessed the transepithelial electrical resistance (TEER) and immunostaining of ZO-1 tight junction, in ARPE-19. After $24 \mathrm{~h}$, the LPS challenge $(2 \mu \mathrm{g} /$ $\mathrm{ml})$ significantly $(p<0.05)$ decreased TEER values, in comparison to untreated cells (control) (Figure 5A). Caffeine, at all tested concentrations, significantly $(p<0.05)$ increased TEER values, in comparison to LPS-treated cells, meaning a restored BRB integrity (Figure 5A). These data were also confirmed by measurement of the apical-to-basolateral permeability of sodium fluorescein (Na-F). Treatment with caffeine $(1-100 \mu \mathrm{M})$, at all considered time points $\left(5^{\prime}-15^{\prime}\right.$ and $30^{\prime} ; 5^{\prime}$ and $30^{\prime}$ Supplementary Figure S1, Supplementary Material), led to a significant $(p<0.05)$ reduction 

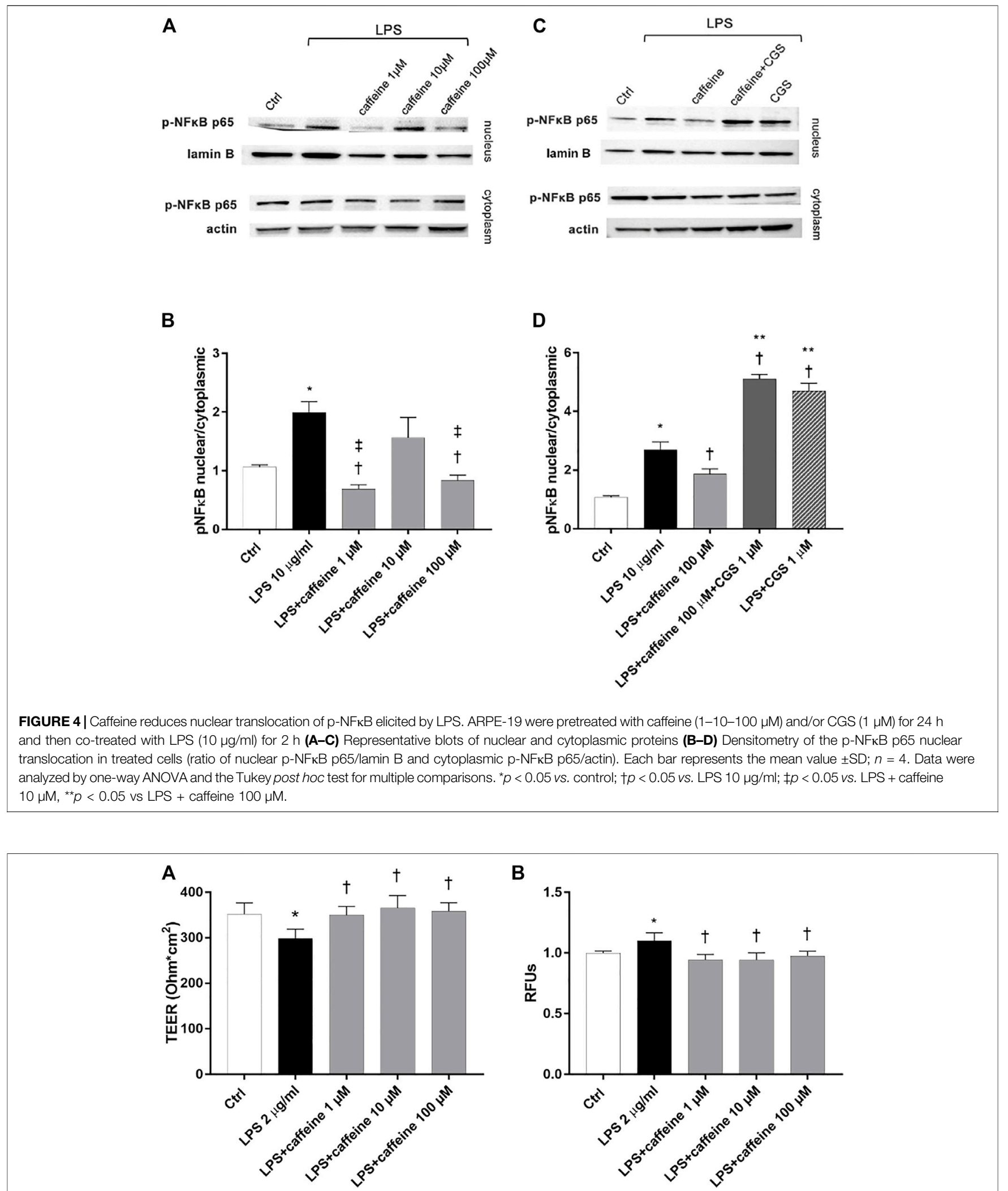

FIGURE 5 | Caffeine protects the ARPE-19 cell monolayer from LPS-induced damage. ARPE-19 were pretreated with caffeine (1-10-100 $\mu \mathrm{M})$ for $24 \mathrm{~h}$ and cotreated with LPS $(2 \mu / \mathrm{ml})$ for $24 \mathrm{~h}$ (A) Caffeine, at all concentrations, increased TEER values, which were reduced by LPS (B) Measurement of apical-to-basolateral Na-F permeability. Representative Na-F permeability measured after $15 \mathrm{~min}$. Values are reported as mean $\pm \mathrm{SD} ; n=4$. Data were analyzed by one-way ANOVA and the Tukey post hoc test for multiple comparisons. ${ }^{*} p<0.05$ vs. control; $\dagger p<0.05$ vs. LPS $2 \mu \mathrm{g} / \mathrm{ml} ;{ }^{\ddagger} p<0.05 \mathrm{vs}$. LPS + caffeine $100 \mu \mathrm{M}$. 

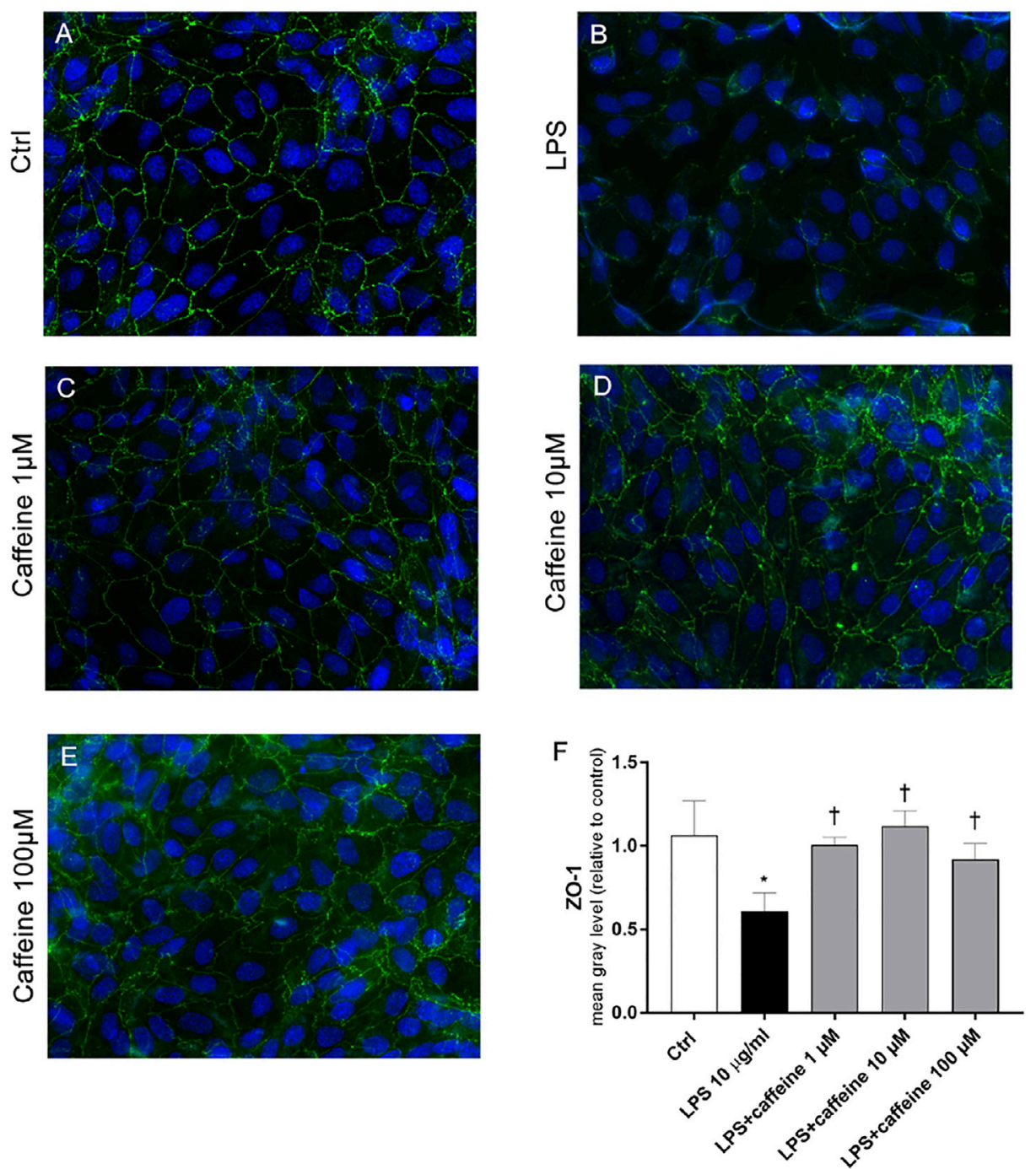

FIGURE 6 | Caffeine re-establishes the BRB integrity through modulation of ZO-1. ARPE-19 were pretreated with caffeine (1-10-100 $\mu \mathrm{M})$ for 24 h and subsequently co-treated with LPS $(10 \mu \mathrm{g} / \mathrm{ml})$ for $72 \mathrm{~h}$. Caffeine, at all concentrations, increased the expression of ZO-1 protein, which was significantly reduced by LPS (A-E) Representative images for the ZO-1 expression in ARPE-19 after treatment with LPS and caffeine. ZO-1 was labeled with FITC (green); nuclei were labeled with DAPI (blue). Images were acquired at 20x magnification (F) Fluorescence semi-quantification of ZO-1 protein (mean gray levels). Values are reported as mean \pm SD; $n=4$. Data were analyzed by one-way ANOVA and the Tukey post hoc test for multiple comparisons. ${ }^{*} p<0.05$ vs. control; ${ }^{\dagger} p<0.05$ vs. LPS $10 \mu \mathrm{g} / \mathrm{ml}$.

of cell permeability, significantly $(p<0.05)$ increased by the LPS challenge (Figure 5B).

According to the instrumental and spectroscopic evaluation of ARPE-19 monolayer integrity, after $72 \mathrm{~h}$, LPS $(10 \mu \mathrm{g} / \mathrm{ml})$ significantly $(p<0.05)$ decreased the ZO-1 expression (Figure 6B), compared to control cells (Figure 6A). The treatment with caffeine $(1,10,100 \mu \mathrm{M})$ reverted this LPS-related damage, reestablishing the ZO-1 expression and BRB integrity (Figure 6C-E).

\section{Effects of Caffeine in Retinal I/R-Injured Mice}

We analyzed the effect of caffeine on the RGC function in I/R mice after $72 \mathrm{~h}$, by means of PERG measurements (Figure $7 \mathrm{~A}$, representative retinal waveforms). As expected, the PERG amplitude decreased ( $50 \%)$ in I/R-injured mice, in comparison to control mice, while caffeine-treated mice showed a PERG amplitude significantly $(p<0.05)$ higher than I/R-injured mice (Figure $7 \mathbf{B}$ ). Indeed, the average value of the PERG amplitude was $11.41 \mu \mathrm{V}$ in the control group, in agreement with previous studies (Porciatti et al., 2010; Romano et al., 2020), while the average value of the PERG amplitude of $\mathrm{I} / \mathrm{R}$ mice was significantly $(p<0.05)$ reduced to $4.51 \mu \mathrm{V}$, compared to the control retina. It is noteworthy that the average value of the PERG amplitude of I/R caffeine-treated mice was $9.41 \mu \mathrm{V}$, suggesting a protective effect of caffeine in terms of RGC function (Figure 7B). No significant changes were observed in PERG latency in all experimental groups, as expected, considering the short time after the injury (Figure 7C). As shown in Figure 8A, I/R injury elicited 


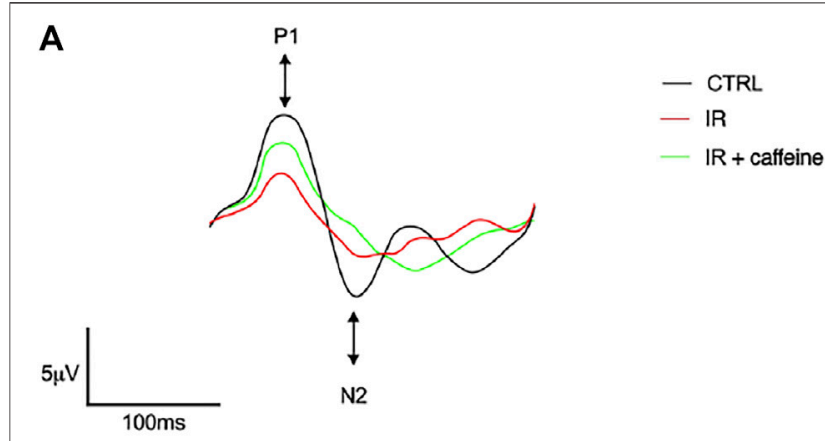

B

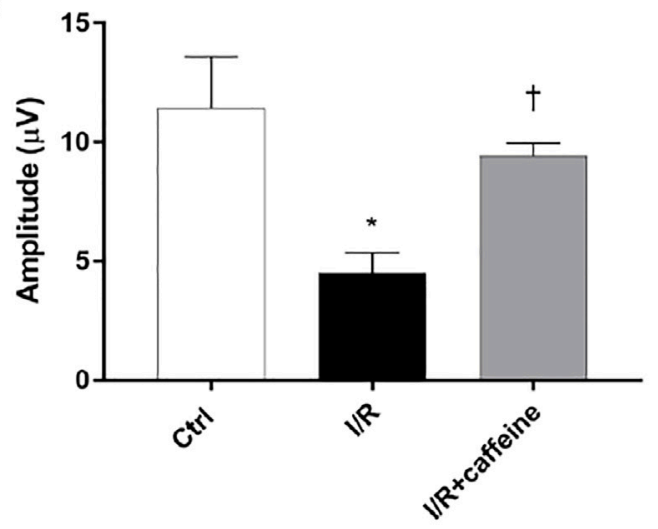

C

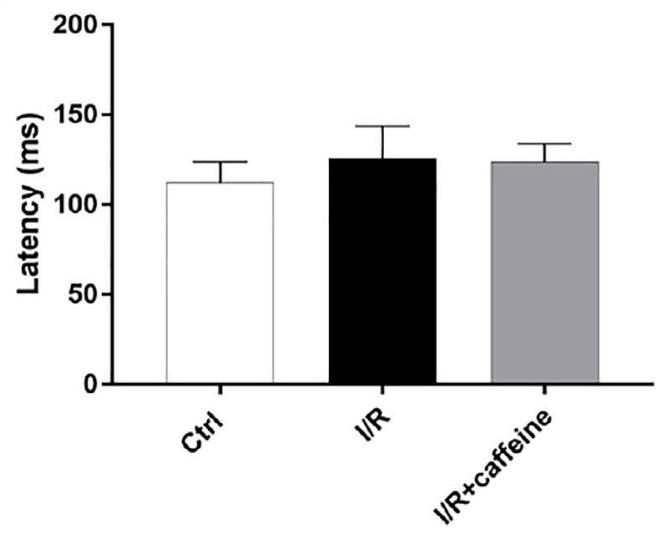

FIGURE 7 | Caffeine counteracts RGC loss of function induced by I/R injury in mouse retinas. RGC function was assessed by the pattern electroretinogram (PERG). (A) Representative waveforms of PERG of all experimental groups (C57BL/6J mouse control (Ctrl), I/R, and I/R + caffeine). Each waveform, deriving from PERG recordings, was analyzed for the peak-to-trough amplitude (P1-N2). (B) Comparison between PERG amplitude values $(\mu \mathrm{V})$ and latency values (ms). (C) of control, I/R, and I/R + caffeine. In each panel, bars represent the mean values \pm S.D; $n=4$. Oneway ANOVA analysis was performed followed by the Tukey post hoc test. ${ }^{*} p<0.05$ vs. Ctrl; ${ }^{\dagger} p<0.05$ vs. I/R. significant $(p<0.05)$ increase of the IL- $6 \mathrm{mRNA}$ expression, that was significantly $(p<0.05)$ counteracted by caffeine treatment. Furthermore, I/R damage significantly $(p<0.05)$ downregulated the mRNA expression of BDNF in mouse retinas, while caffeine significantly induced $(p<0.05)$ the BDNF mRNA expression compared to the I/R group (Figure $\mathbf{8 B}$ ).

\section{DISCUSSION}

Caffeine is approved for clinical use, and it is indicated for the treatment of the apnea of prematurity (Abdel-Hady, 2015). Increasing interest on caffeine has risen from several in vitro and in vivo evidence of neuroprotective effects in the model of brain neurodegenerative diseases (Chen et al., 2001, Chen et al., 2008a; Singhal et al., 2015; Akomolafe et al., 2017). Moreover, some clinical trials are focusing on the therapeutic potential of this natural stimulatory compound in Alzheimer's disease and Parkinson's disease (NCT01190735; NCT05009199; NCT01190735; NCT04570085). Previous studies reported the anti-inflammatory, anti-oxidative, and neuroprotective properties of caffeine (Jung et al., 2017; Kolahdouzan and Hamadeh, 2017; Metro et al., 2017). Only few studies have investigated the effects of caffeine on retinal diseases. On this regards, the Coimbra Eye Study, an epidemiological cross-sectional study, evidenced an inverse correlation between consumption of caffeine and AMD progression. The authors concluded that caffeine could be a promising nutritional supplement for slow-down of the AMD progression (Campochiaro et al., 2016; Raimundo et al., 2018), highlighting the need for further pre-clinical pharmacological studies on caffeine and retinal diseases. Based on this evidence, we evaluated, for the first time, the anti-inflammatory and neuroprotective effect of caffeine, in human RPE cells and mouse retinas challenged with LPS (Ozal et al., 2018) and ischemia/reperfusion (Conti et al., 2021), respectively.

LPS elicits retinal inflammation through activation of TLR-4, which is expressed in RPE cells, leading to inflammatory cytokine release and causing several degenerative processes (Kumar et al., 2004; Chen et al., 2017; Klettner et al., 2020). It has been demonstrated that caffeine suppresses the LPS-induced inflammatory response, reducing the expression of several inflammatory mediators in different types of cells, such as microglia and monocyte/macrophage-like cells (Kang et al., 2012; Hwang et al., 2016). In accordance with these findings, we demonstrated that caffeine exerted anti-inflammatory and neuroprotective effects also in RPE cells and in the retina of mice after LPS and ischemia insults, respectively. Caffeine reduced the mRNA expression of TNF- $\alpha$, IL-6, and IL- $1 \beta$ in RPE cells after LPS exposure. Furthermore, caffeine significantly counteracted the p-NFkB p65 nuclear translocation in RPE cells exposed to LPS, showing a biphasic effect, already observed in other systems ( $\mathrm{Su}$ et al., 2013) and with other compounds (Calabrese, 2016; Kurano et al., 2016). Finally, caffeine protected RPE cells also through the upregulation of BDNF, as already reported in different systems (Costa et al., 2008; Sallaberry et al., 2013; Lao-Peregrín et al., 2017). Moreover, retinal $\mathrm{BDNF}$ was also upregulated by caffeine in our retinal $\mathrm{I} / \mathrm{R}$ in vivo model; in this paradigm, we also demonstrated that caffeine 

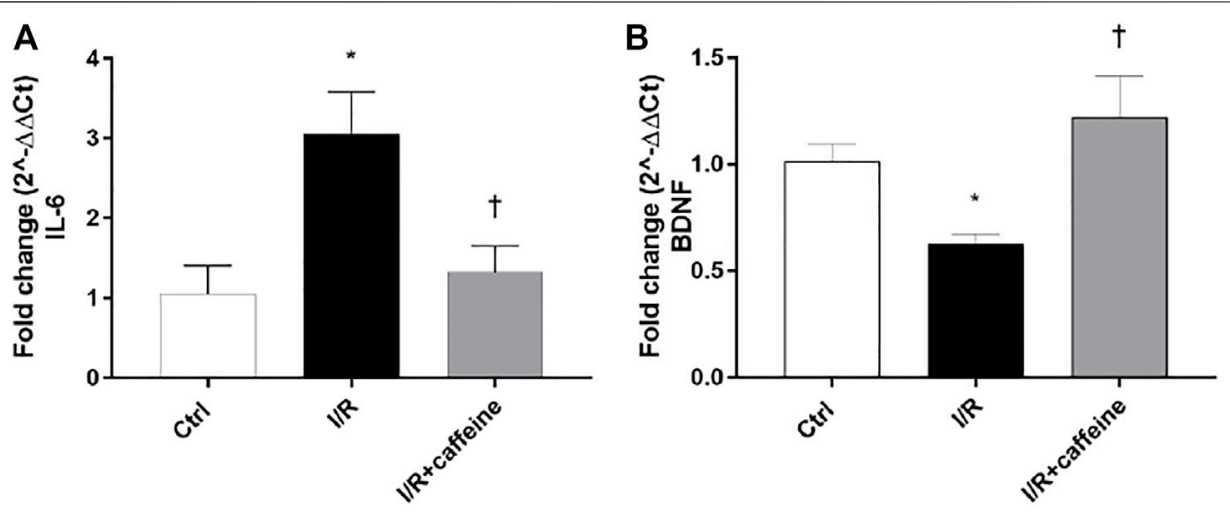

FIGURE 8 | Caffeine counteracts inflammation and elicits the BDNF expression in I/R mice. After $72 \mathrm{~h}$, caffeine was able to revert the upregulation of IL-6 mRNA levels (A) elicited by I/R damage in mouse retinas. BDNF mRNA levels were upregulated by caffeine, compared to I/R mice (B). Values were reported as mean \pm SD; $n=4$. Data were analyzed by one-way ANOVA and the Tukey post hoc test for multiple comparisons. ${ }^{*} p<0.05$ vs. control; ${ }^{\dagger} p<0.05$ vs. I/R.

reduced IL-6 mRNA levels in comparison to $\mathrm{I} / \mathrm{R}$ mice. BDNF is strongly reduced in several neurodegenerative processes both in the brain (Howells et al., 2000; Leyhe et al., 2008) and in the retina (Johnson et al., 2009; Kimura et al., 2016; Oddone et al., 2017; Platania et al., 2019; Conti et al., 2021). The overexpression of BDNF, and the reduced expression of IL-6, elicited by caffeine treatment in the retinal I/R model, could explain the protection of RGCs showed by PERG analysis in mice. Moreover, several studies demonstrated that some retinal diseases such as AMD are characterized by the abnormal expression and irregular distribution of tight junction proteins in RPE cells (Du et al., 2013). Hence, it is well known that LPS affects the epithelial integrity (Zheng et al., 2018; He et al., 2019), reducing the expression of ZO-1 protein and diminishing TEER values, in ARPE19 cell monolayers (Chen et al., 2017; Zou et al., 2018; Hernandez et al., 2021). In this study, we confirmed that the LPS insult reduced the ARPE-19 monolayer integrity, as shown by instrumental (TEER measurements), spectroscopic ( $\mathrm{NaF}$ permeability assays), and immunocytochemistry analyses. The pretreatment with caffeine brought TEER values and NaF permeability to levels shown by ARPE-19-negative control cells. Furthermore, caffeine restored the ZO-1 expression, in ARPE-19 exposed to LPS treatment. The present findings are in line with the previous studies, which demonstrated that caffeine is able to prevent cell-cell interaction network disruption, not only as regard as the retinal barrier but also in the blood-brain barrier (BBB) (Chen et al., 2008a, Chen et al., 2008b; Maugeri et al., 2017). Caffeine has an interesting pharmacological profile, and several studies demonstrated that the antagonism of $\mathrm{A}_{2 \mathrm{~A}}$ receptors modulates neuroinflammation in retinal ganglion cells (Madeira et al., 2016; Boia et al., 2017), in microglia (Madeira et al., 2018), and in neuronal cells (Rebola et al., 2011). Based on this evidence, we supported the hypothesis that caffeine exerts its neuroprotective and anti-inflammatory effects through $\mathrm{A}_{2 \mathrm{~A}}$ receptor signaling because the agonist (CGS 21680) counteracted the effects of caffeine in RPE cells exposed to LPS. In conclusion, we demonstrated that caffeine was able to protect RPE cells and RGCs from damage elicited by LPS and ischemia, respectively, showing a key role of BDNF. These findings suggest that caffeine may be a potential candidate for retinal degeneration treatment.

\section{DATA AVAILABILITY STATEMENT}

The original contributions presented in the study are included in the article/Supplementary Material; further inquiries can be directed to the corresponding author.

\section{ETHICS STATEMENT}

The animal study was reviewed and approved by the University of Catania (Italy) Ethics Committee.

\section{AUTHOR CONTRIBUTIONS}

$\mathrm{CB}$ made substantial contributions to conception, design, and interpretation of data. FC, FL, and GLR carried out experiments. FC, FL, and CBMP carried out formal analysis of data. FC, FL, CBMP, and CB wrote the initial draft of the manuscript. $\mathrm{CB}$ and $\mathrm{FD}$ reviewed the manuscript critically for important intellectual content and gave final approval of the version to be submitted.

\section{FUNDING}

This research was funded by the University of Catania research grant PIAno inCEntivi RIcerca (PIACERI) Ateneo 2020/2022 (NanoRET). GLR was supported by the PON AIM R\&I 20142020-E66C18001260007.

\section{SUPPLEMENTARY MATERIAL}

The Supplementary Material for this article can be found online at: https://www.frontiersin.org/articles/10.3389/fphar.2021.824885/ full\#supplementary-material 


\section{REFERENCES}

Abdel-Hady, H. (2015). Caffeine Therapy in Preterm Infants. World J. Clin. Pediatr. 4, 81. doi:10.5409/wjcp.v4.i4.81

Akomolafe, S. F., Akinyemi, A. J., Ogunsuyi, O. B., Oyeleye, S. I., Oboh, G., Adeoyo, O. O., et al. (2017). Effect of Caffeine, Caffeic Acid and Their Various Combinations on Enzymes of Cholinergic, Monoaminergic and Purinergic Systems Critical to Neurodegeneration in Rat Brain-In Vitro. Neurotoxicology. 62, 6-13. doi:10.1016/j.neuro.2017.04.008

Alves, C. B., Almeida, A. S., Marques, D. M., Faé, A. H. L., Machado, A. C. L., Oliveira, D. L., et al. (2020). Caffeine and Adenosine A2A Receptors Rescue Neuronal Development In Vitro of Frontal Cortical Neurons in a Rat Model of Attention Deficit and Hyperactivity Disorder. Neuropharmacology. 166, 107782. doi:10.1016/j.neuropharm.2019.107782

Amadio, M., Pascale, A., Cupri, S., Pignatello, R., Osera, C., D Agata, V., et al. (2016). Nanosystems Based on siRNA Silencing HuR Expression Counteract Diabetic Retinopathy in Rat. Pharmacol. Res. 111, 713-720. doi:10.1016/ j.phrs.2016.07.042

Bahrami, B., Shen, W., Zhu, L., Zhang, T., Chang, A., and Gillies, M. C. (2019). Effects of VEGF Inhibitors on Human Retinal Pigment Epithelium Under High Glucose and Hypoxia. Clin. Exp. Ophthalmol. 47, 1074-1081. doi:10.1111/ ceo. 13579

Boia, R., Elvas, F., Madeira, M. H., Aires, I. D., Rodrigues-Neves, A. C., Tralhão, P., et al. (2017). Treatment with A2A Receptor Antagonist KW6002 and Caffeine Intake Regulate Microglia Reactivity and Protect Retina against Transient Ischemic Damage. Cell Death Dis. 8, e3065. doi:10.1038/cddis.2017.451

Bucolo, C., Drago, F., Lin, L. R., and Reddy, V. N. (2005). Neuroactive Steroids Protect Retinal Pigment Epithelium Against Oxidative Stress. Neuroreport. 16 (11), 1203-1207. doi:10.1097/00001756-200508010-00014

Bucolo, C., Gozzo, L., Longo, L., Mansueto, S., Vitale, D. C., and Drago, F. (2018). Long-Term Efficacy and Safety Profile of Multiple Injections of Intravitreal Dexamethasone Implant to Manage Diabetic Macular Edema: A Systematic Review of Real-World Studies. J. Pharmacol. Sci. 138 (4), 219-232. doi:10.1016/ j.jphs.2018.11.001

Calabrese, E. J. (2016). Preconditioning Is Hormesis Part II: How the Conditioning Dose Mediates protection: Dose Optimization Within Temporal and Mechanistic Frameworks. Pharmacol. Res. 110, 265-275. doi:10.1016/ j.phrs.2015.12.020

Campochiaro, P. A., Aiello, L. P., and Rosenfeld, P. J. (2016). Anti-Vascular Endothelial Growth Factor Agents in the Treatment of Retinal Disease. Ophthalmology. 123, S78-S88. doi:10.1016/j.ophtha.2016.04.056

Carman, A. J., Dacks, P. A., Lane, R. F., Shineman, D. W., and Fillit, H. M. (2014). Current Evidence for the Use of Coffee and Caffeine to Prevent Age-Related Cognitive Decline and Alzheimer's Disease. J. Nutr. Health Aging. 18, 383-392. doi:10.1007/s12603-014-0021-7

Chen, C., Guo, D., and Lu, G. (2017). Wogonin Protects Human Retinal Pigment Epithelium Cells From LPS-Induced Barrier Dysfunction and Inflammatory Responses by Regulating the TLR4/NF-Kb Signaling Pathway. Mol. Med. Rep. 15, 2289-2295. doi:10.3892/mmr.2017.6252

Chen, J.-F., Xu, K., Petzer, J. P., Staal, R., Xu, Y.-H., Beilstein, M., et al. (2001). Neuroprotection by Caffeine and A2AAdenosine Receptor Inactivation in a Model of Parkinson's Disease. J. Neurosci. 21, RC143. doi:10.1523/jneurosci.2110-j0001.2001

Chen, X., Gawryluk, J. W., Wagener, J. F., Ghribi, O., and Geiger, J. D. (2008a). Caffeine Blocks Disruption of Blood Brain Barrier in a Rabbit Model of Alzheimer's Disease. J. Neuroinflammation. 5, 12. doi:10.1186/1742-20945-12

Chen, X., Lan, X., Roche, I., Liu, R., and Geiger, J. D. (2008b). Caffeine Protects against MPTP-Induced Blood-Brain Barrier Dysfunction in Mouse Striatum. J. Neurochem. 107 (4), 1147-1157. doi:10.1111/j.1471-4159.2008.05697.x

Chou, T.-H., Musada, G., Romano, G., Bolton, E., and Porciatti, V. (2018). Anesthetic Preconditioning as Endogenous Neuroprotection in Glaucoma. Int. J. Mol. Sci. 19, 237. doi:10.3390/ijms19010237

Conti, F., Romano, G. L., Eandi, C. M., Toro, M. D., Rejdak, R., Di Benedetto, G., et al. (2021). Brimonidine Is Neuroprotective in Animal Paradigm of Retinal Ganglion Cell Damage. Front. Pharmacol. 12, 705405 . doi:10.3389/ fphar.2021.705405
Costa, M. S., Botton, P. H., Mioranzza, S., Ardais, A. P., Moreira, J. D., Souza, D. O., et al. (2008). Caffeine Improves Adult Mice Performance in the Object Recognition Task and Increases BDNF and TrkB Independent on PhosphoCREB Immunocontent in the hippocampus. Neurochem. Int. 53, 89-94. doi:10.1016/j.neuint.2008.06.006

Dabouz, R., Cheng, C. W. H., Abram, P., Omri, S., Cagnone, G., Sawmy, K. V., et al. (2020). An Allosteric Interleukin-1 Receptor Modulator Mitigates Inflammation and Photoreceptor Toxicity in a Model of Retinal Degeneration. J. Neuroinflammation. 17, 359. doi:10.1186/s12974-02002032-8

Dai, S.-S., and Zhou, Y.-G. (2011). Adenosine 2A Receptor: A Crucial Neuromodulator with Bidirectional Effect in Neuroinflammation and Brain Injury. Rev. Neurosci. 22, 231. doi:10.1515/RNS.2011.020

Dall'lgna, O. P., Porciúncula, L. O., Souza, D. O., Cunha, R. A., and Lara, D. R. (2003). Neuroprotection by Caffeine and Adenosine A2A Receptor Blockade of $\beta$-Amyloid Neurotoxicity. Br. J. Pharmacol. 138, 1207-1209. doi:10.1038/ sj.bjp. 0705185

Do, J. Y., Kim, J., Kim, M.-J., Lee, J. Y., Park, S.-Y., Yanai, R., et al. (2020). Fursultiamine Alleviates Choroidal Neovascularization by Suppressing Inflammation and Metabolic Reprogramming. Invest. Ophthalmol. Vis. Sci. 61, 24. doi:10.1167/IOVS.61.12.24

Du, M., Wu, M., Fu, D., Yang, S., Chen, J., Wilson, K., et al. (2013). Effects of Modified LDL and HDL on Retinal Pigment Epithelial Cells: A Role in Diabetic Retinopathy? Diabetologia. 56, 2318-2328. doi:10.1007/s00125-013-2986-x

Fredholm, B. B., Ijzerman, A. P., Jacobson, K. A., Linden, J., and Müller, C. E. (2011). International Union of Basic and Clinical Pharmacology. LXXXI. Nomenclature and classification of adenosine receptors-an update.. Pharmacol. Rev. 63 (1), 1-34. doi:10.1124/pr.110.003285

Fresta, C. G., Fidilio, A., Caruso, G., Caraci, F., Giblin, F. J., Leggio, G. M., et al. (2020). A New Human Blood-Retinal Barrier Model Based on Endothelial Cells, Pericytes, and Astrocytes. Int. J. Mol. Sci. 21 (5), 1636. doi:10.3390/ ijms 21051636

Giurdanella, G., Anfuso, C. D., Olivieri, M., Lupo, G., Caporarello, N., Eandi, C. M., et al. (2015). Aflibercept, Bevacizumab and Ranibizumab Prevent GlucoseInduced Damage in Human Retinal Pericytes In Vitro, through a PLA2/COX-2/ VEGF-A Pathway. Biochem. Pharmacol. 96 (3), 278-287. doi:10.1016/ j.bcp.2015.05.017

Giurdanella, G., Lazzara, F., Caporarello, N., Lupo, G., Anfuso, C. D., Eandi, C. M., et al. (2017). Sulodexide Prevents Activation of the PLA2/COX-2/VEGF Inflammatory Pathway in Human Retinal Endothelial Cells by Blocking the Effect of AGE/RAGE. Biochem. Pharmacol. 142, 145-154. doi:10.1016/ j.bcp.2017.06.130

Gurley, B. J., Steelman, S. C., and Thomas, S. L. (2015). Multi-ingredient, CaffeineContaining Dietary Supplements: History, Safety, and Efficacy. Clin. Ther. 37, 275-301. doi:10.1016/j.clinthera.2014.08.012

Gustavsson, C., Agardh, C. D., Hagert, P., and Agardh, E. (2008). Inflammatory Markers in Nondiabetic and Diabetic Rat Retinas Exposed to Ischemia Followed by Reperfusion. Retina. 28, 645-652. doi:10.1097/ IAE.0b013e31815ec32d

He, C., Deng, J., Hu, X., Zhou, S., Wu, J., Xiao, D., et al. (2019). Vitamin A Inhibits the Action of LPS on the Intestinal Epithelial Barrier Function and Tight junction Proteins. Food Funct. 10, 1235-1242. doi:10.1039/c8fo01123k

Hernandez, M., Recalde, S., González-Zamora, J., Bilbao-Malavé, V., Sáenz de Viteri, M., Bezunartea, J., et al. (2021). Anti-inflammatory and Anti-oxidative Synergistic Effect of Vitamin D and Nutritional Complex on Retinal Pigment Epithelial and Endothelial Cell Lines Against Age-Related Macular Degeneration. Nutrients. 13, 1423. doi:10.3390/nu13051423

Holtkamp, G. M., Van Rossem, M., De Vos, A. F., Willekens, B., Peek, R., and Kijlstra, A. (1998). Polarized Secretion of IL-6 and IL-8 by Human Retinal Pigment Epithelial Cells. Clin. Exp. Immunol. 112, 34-43. doi:10.1046/j.13652249.1998.00560.x

Hosny, E. N., Sawie, H. G., Elhadidy, M. E., and Khadrawy, Y. A. (2019). Evaluation of Antioxidant and Anti-Inflammatory Efficacy of Caffeine in Rat Model of Neurotoxicity. Nutr. Neurosci. 22, 789-796. doi:10.1080/ 1028415X.2018.1446812

Howells, D. W., Porritt, M. J., Wong, J. Y. F., Batchelor, P. E., Kalnins, R., Hughes, A. J., et al. (2000). Reduced BDNF mRNA Expression in the Parkinson's Disease Substantia Nigra. Exp. Neurol. 166, 127-135. doi:10.1006/exnr.2000.7483 
Hwang, J.-H., Kim, K.-J., Ryu, S.-J., and Lee, B.-Y. (2016). Caffeine Prevents LPSInduced Inflammatory Responses in RAW264.7 Cells and Zebrafish. ChemicoBiological Interactions. 248, 1-7. doi:10.1016/j.cbi.2016.01.020

Ibrahim, M. K., Kamal, M., Tikamdas, R., Nouh, R. A., Tian, J., and Sayed, M. (2020). Effects of Chronic Caffeine Administration on Behavioral and Molecular Adaptations to Sensory Contact Model Induced Stress in Adolescent Male Mice. Behav. Genet. 50, 374-383. doi:10.1007/s10519-02010003-1

Inanc Tekin, M., Sekeroglu, M. A., Demirtas, C., Tekin, K., Doguizi, S., Bayraktar, S., et al. (2018). Brain-derived Neurotrophic Factor in Patients with AgeRelated Macular Degeneration and its Correlation with Retinal Layer Thicknesses. Invest. Ophthalmol. Vis. Sci. 59, 2833. doi:10.1167/iovs.18-24030

Izumi-Nagai, K., Nagai, N., Ozawa, Y., Mihara, M., Ohsugi, Y., Kurihara, T., et al. (2007). Interleukin-6 Receptor-Mediated Activation of Signal Transducer and Activator of Transcription-3 (STAT3) Promotes Choroidal Neovascularization. Am. J. Pathol. 170, 2149-2158. doi:10.2353/ajpath.2007.061018

Jacobson, K. A., Gao, Z. G., Matricon, P., Eddy, M. T., and Carlsson, J. (2020). Adenosine A 2A Receptor Antagonists: from Caffeine to Selective NonXanthines. Br. J. Pharmacol. 1-16. doi:10.1111/bph.15103

Johnson, E. C., Guo, Y., Cepurna, W. O., and Morrison, J. C. (2009). Neurotrophin Roles in Retinal Ganglion Cell Survival: Lessons from Rat Glaucoma Models. Exp. Eye Res. 88, 808-815. doi:10.1016/j.exer.2009.02.004

Jung, S., Kim, M. H., Park, J. H., Jeong, Y., and Ko, K. S. (2017). Cellular Antioxidant and Anti-Inflammatory Effects of Coffee Extracts with Different Roasting Levels. J. Med. Food. 20, 626-635. doi:10.1089/ jmf.2017.3935

Kang, C.-H., Jayasooriya, R. G. P. T., Dilshara, M. G., Choi, Y. H., Jeong, Y.-K., Kim, N. D., et al. (2012). Caffeine Suppresses Lipopolysaccharide-Stimulated BV2 Microglial Cells by Suppressing Akt-Mediated NF-Kb Activation and ERK Phosphorylation. Food Chem. Toxicol. 50, 4270-4276. doi:10.1016/ j.fct.2012.08.041

Katz, M. L. (2002). Potential Role of Retinal Pigment Epithelial Lipofuscin Accumulation in Age-Related Macular Degeneration. Arch. Gerontol. Geriatr. 34 (3), 359-370. doi:10.1016/S0167-4943(02)00012-2

Kimura, A., Namekata, K., Guo, X., Harada, C., and Harada, T. (2016). Neuroprotection, Growth Factors and BDNF-TRKB Signalling in Retinal Degeneration. Int. J. Mol. Sci. 17, 1584. doi:10.3390/ijms17091584

Klettner, A., Brinkmann, A., Winkelmann, K., Käckenmeister, T., Hildebrandt, J., and Roider, J. (2020). Effect of Long-Term Inflammation on Viability and Function of RPECells. Exp. Eye Res. 200, 108214. doi:10.1016/ j.exer.2020.108214

Kolahdouzan, M., and Hamadeh, M. J. (2017). The Neuroprotective Effects of Caffeine in Neurodegenerative Diseases. CNS Neurosci. Ther. 23, 272-290. doi: $10.1111 / \mathrm{cns} .12684$

Krogh Nielsen, M., Subhi, Y., Molbech, C. R., Falk, M. K., Nissen, M. H., and Sørensen, T. L. (2019). Systemic Levels of Interleukin-6 Correlate with Progression Rate of Geographic Atrophy Secondary to Age-Related Macular Degeneration. Invest. Ophthalmol. Vis. Sci. 60, 202. doi:10.1167/iovs.18-25878

Kumar, M. V., Nagineni, C. N., Chin, M. S., Hooks, J. J., and Detrick, B. (2004). Innate Immunity in the Retina: Toll-like Receptor (TLR) Signaling in Human Retinal Pigment Epithelial Cells. J. Neuroimmunology. 153, 7-15. doi:10.1016/ j.jneuroim.2004.04.018

Kurano, M., Hara, M., Nojiri, T., Ikeda, H., Tsukamoto, K., and Yatomi, Y. (2016). Resveratrol Exerts a Biphasic Effect on Apolipoprotein M. Br. J. Pharmacol. 173, 222-233. doi:10.1111/bph.13360

Lao-Peregrín, C., Ballesteros, J. J., Fernández, M., Zamora-Moratalla, A., Saavedra, A., Gómez Lázaro, M., et al. (2017). Caffeine-mediated BDNF Release Regulates Long-Term Synaptic Plasticity through Activation of IRS2 Signaling. Addict. Biol. 22, 1706-1718. doi:10.1111/adb.12433

Leggio, G. M., Di Marco, R., Gulisano, W., D’Ascenzo, M., Torrisi, S. A., Geraci, F., et al. (2019). Dopaminergic-GABAergic Interplay and Alcohol Binge Drinking. Pharmacol. Res. 141, 384-391. doi:10.1016/j.phrs.2019.01.022

Leyhe, T., Stransky, E., Eschweiler, G. W., Buchkremer, G., and Laske, C. (2008). Increase of BDNF Serum Concentration during Donepezil Treatment of Patients with Early Alzheimer's Disease. Eur. Arch. Psychiatry Clin. Neurosc. 258, 124-128. doi:10.1007/s00406-007-0764-9

Liu, G., Zhang, W., Guo, J., Kong, F., Zhou, S., Chen, S., et al. (2018). Adenosine Binds Predominantly to Adenosine Receptor Al Subtype in Astrocytes and
Mediates an Immunosuppressive Effect. Brain Res. 1700, 47-55. doi:10.1016/ j.brainres.2018.06.021

Madeira, M. H., Boia, R., Elvas, F., Martins, T., Cunha, R. A., Ambrósio, A. F., et al. (2016). Selective A2A Receptor Antagonist Prevents Microglia-Mediated Neuroinflammation and Protects Retinal Ganglion Cells from High Intraocular Pressure-Induced Transient Ischemic Injury. Translational Res. 169, 112-128. doi:10.1016/j.trsl.2015.11.005

Madeira, M. H., Rashid, K., Ambrósio, A. F., Santiago, A. R., and Langmann, T. (2018). Blockade of Microglial Adenosine A2A Receptor Impacts Inflammatory Mechanisms, Reduces ARPE-19 Cell Dysfunction and Prevents Photoreceptor Loss In Vitro. Sci. Rep. 8, 2272. doi:10.1038/s41598-018-20733-2

Maugeri, G., D’Amico, A. G., Rasà, D. M., La Cognata, V., Saccone, S., Federico, C., et al. (2017). Caffeine Prevents Blood Retinal Barrier Damage in a Model, In Vitro, of Diabetic Macular Edema. J. Cell. Biochem. 118, 2371-2379. doi:10.1002/jcb.25899

Metro, D., Cernaro, V., Santoro, D., Papa, M., Buemi, M., Benvenga, S., et al. (2017). Beneficial Effects of Oral Pure Caffeine on Oxidative Stress. J. Clin. Translational Endocrinol. 10, 22-27. doi:10.1016/j.jcte.2017.10.001

Mitchell, D. C., Knight, C. A., Hockenberry, J., Teplansky, R., and Hartman, T. J. (2014). Beverage Caffeine Intakes in the U.S. Food Chem. Toxicol. 63, 136-142. doi:10.1016/j.fct.2013.10.042

Oddone, F., Roberti, G., Micera, A., Busanello, A., Bonini, S., Quaranta, L., et al. (2017). Exploring Serum Levels of Brain Derived Neurotrophic Factor and Nerve Growth Factor across Glaucoma Stages. PLoS One. 12, e0168565. doi:10.1371/journal.pone.0168565

Osborne, N. N., Casson, R. J., Wood, J. P. M., Chidlow, G., Graham, M., and Melena, J. (2004). Retinal Ischemia: Mechanisms of Damage and Potential Therapeutic Strategies. Prog. Retin. Eye Res. 23, 91-147. doi:10.1016/ j.preteyeres.2003.12.001

Ozal, S. A., Turkekul, K., Gurlu, V., Guclu, H., and Erdogan, S. (2018). Esculetin Protects Human Retinal Pigment Epithelial Cells from LipopolysaccharideInduced Inflammation and Cell Death. Curr. Eye Res. 43, 1169-1176. doi:10.1080/02713683.2018.1481517

Park, S., Jang, J. S., and Hong, S. M. (2007). Long-term Consumption of Caffeine Improves Glucose Homeostasis by Enhancing Insulinotropic Action through Islet Insulin/Insulin-like Growth Factor 1 Signaling in Diabetic Rats. Metabolism. 56, 599-607. doi:10.1016/j.metabol.2006.12.004

Platania, C. B. M., Fisichella, V., Fidilio, A., Geraci, F., Lazzara, F., Leggio, G. M., et al. (2017). Topical Ocular Delivery of TGF- $\beta 1$ to the Back of the Eye: Implications in Age-Related Neurodegenerative Diseases. Int. J. Mol. Sci. 18 (10), 2076. doi:10.3390/ijms18102076

Platania, C. B. M., Maisto, R., Trotta, M. C., D’Amico, M., Rossi, S., Gesualdo, C., et al. (2019). Retinal and Circulating miRNA Expression Patterns in Diabetic Retinopathy: An In Silico and In Vivo Approach. Br. J. Pharmacol. 176 (13), 2179-2194. doi:10.1111/bph.14665

Ponnalagu, M., Subramani, M., Jayadev, C., Shetty, R., and Das, D. (2017). Retinal Pigment Epithelium-Secretome: A Diabetic Retinopathy Perspective. Cytokine. 95, 126-135. doi:10.1016/j.cyto.2017.02.013

Porciatti, V., Chou, T. H., and Feuer, W. J. (2010). C57BL/6J, DBA/2J, and DBA/ 2J.Gpnmb+ Mice Have Different Visual Signal Processing in the Inner Retina. Mol. 16, 2939-2947.

Porciatti, V. (2015). Electrophysiological Assessment of Retinal Ganglion Cell Function. Exp. Eye Res. 141, 164-170. doi:10.1016/j.exer.2015.05.008

Raimundo, M., Mira, F., Cachulo, M. d. L., Barreto, P., Ribeiro, L., Farinha, C., et al. (2018). Adherence to a Mediterranean Diet, Lifestyle and Age-Related Macular Degeneration: the Coimbra Eye Study - Report 3. Acta Ophthalmol. 96, e926-e932. doi:10.1111/aos.13775

Rebola, N., Simões, A. P., Canas, P. M., Tomé, A. R., Andrade, G. M., Barry, C. E., et al. (2011). Adenosine A2A Receptors Control Neuroinflammation and Consequent Hippocampal Neuronal Dysfunction. J. Neurochem. 117, 100-111. doi:10.1111/j.1471-4159.2011.07178.x

Rivera, J. C., Dabouz, R., Noueihed, B., Omri, S., Tahiri, H., and Chemtob, S. (2017). Ischemic Retinopathies: Oxidative Stress and Inflammation. Oxidative Med. Cell Longevity. 2017, 1-16. doi:10.1155/2017/3940241

Romano, G. L., Amato, R., Lazzara, F., Porciatti, V., Chou, T. H., Drago, F., et al. (2020). P2X7 Receptor Antagonism Preserves Retinal Ganglion Cells in Glaucomatous Mice. Biochem. Pharmacol. 180, 114199. doi:10.1016/ j.bcp.2020.114199 
Romano, G. L., Platania, C. B., Forte, S., Salomone, S., Drago, F., and Bucolo, C. (2015). MicroRNA Target Prediction in Glaucoma. Prog. Brain Res. 220, 217-240. doi:10.1016/bs.pbr.2015.04.013

Romano, G. L., Platania, C. B. M., Drago, F., Salomone, S., Ragusa, M., Barbagallo, C., et al. (2017). Retinal and Circulating miRNAs in Age-Related Macular Degeneration: An In Vivo Animal and Human Study. Front. Pharmacol. 8, 168. doi:10.3389/fphar.2017.00168

Sallaberry, C., Nunes, F., Costa, M. S., Fioreze, G. T., Ardais, A. P., Botton, P. H. S., et al. (2013). Chronic Caffeine Prevents Changes in Inhibitory Avoidance Memory and Hippocampal BDNF Immunocontent in Middle-Aged Rats. Neuropharmacology. 64, 153-159. doi:10.1016/j.neuropharm.2012.07.010

Salminen, A., and Kaarniranta, K. (2009). NF- $\mathrm{B}$ Signaling in the Aging Process. J. Clin. Immunol. 29, 397-405. doi:10.1007/s10875-009-9296-6

Sarao, V., Veritti, D., Boscia, F., and Lanzetta, P. (2014). Intravitreal Steroids for the Treatment of Retinal Diseases. Scientific World J. 2014, 1-14. doi:10.1155/2014/ 989501

Sc, Y., and Muralidhara (2016). Beneficial Role of Coffee and Caffeine in Neurodegenerative Diseases: A Minireview. AIMS Public Heal. 3, 407-422. doi:10.3934/publichealth.2016.2.407

Singhal, N. K., Agarwal, S., Bhatnagar, P., Tiwari, M. N., Tiwari, S. K., Srivastava, G., et al. (2015). Mechanism of Nanotization-Mediated Improvement in the Efficacy of Caffeine against 1-Methyl-4-Phenyl-1,2,3,6-TetrahydropyridineInduced Parkinsonism. J. Biomed. Nanotechnol. 11, 2211-2222. doi:10.1166/ jbn.2015.2107

Stankowska, D. L., Dibas, A., Li, L., Zhang, W., Krishnamoorthy, V. R., Chavala, S. H., et al. (2019). Hybrid Compound Sa-2 Is Neuroprotective in Animal Models of Retinal Ganglion Cell Death. Invest. Ophthalmol. Vis. Sci. 60, 3064. doi:10.1167/iovs.18-25999

Su, S.-J., Chang, K.-L., Su, S.-H., Yeh, Y.-T., Shyu, H.-W., and Chen, K.-M. (2013). Caffeine Regulates Osteogenic Differentiation and Mineralization of Primary Adipose-Derived Stem Cells and a Bone Marrow Stromal Cell Line. Int. J. Food Sci. Nutr. 64, 429-436. doi:10.3109/09637486.2012.759184

Tang, J., and Kern, T. S. (2011). Inflammation in Diabetic Retinopathy. Prog. Retin. Eye Res. 30, 343-358. doi:10.1016/j.preteyeres.2011.05.002

Ulbrich, F., Hagmann, C., Buerkle, H., Romao, C. C., Schallner, N., Goebel, U., et al. (2017). The Carbon Monoxide Releasing Molecule ALF-186 Mediates AntiInflammatory and Neuroprotective Effects via the Soluble Guanylate Cyclase SS1 in Rats' Retinal Ganglion Cells after Ischemia and Reperfusion Injury. J. Neuroinflammation. 14, 130. doi:10.1186/s12974-017-0905-7

Van Lookeren Campagne, M., Lecouter, J., Yaspan, B. L., and Ye, W. (2014). Mechanisms of Age-Related Macular Degeneration and Therapeutic Opportunities. J. Pathol. 232, 151-164. doi:10.1002/path.4266

Wan, W. J., Cui, D. M., Yang, X., Hu, J. M., Li, C. X., Hu, S. L., et al. (2011). Expression of Adenosine Receptors in Human Retinal Pigment Epithelium
Cells In Vitro. Chin. Med. J. (Engl). 124 (8), 1139-1144. doi:10.3760/ cma.j.issn.0366-6999.2011.08.004

Wang, H., Guan, W., Yang, W., Wang, Q., Zhao, H., Yang, F., et al. (2014). Caffeine Inhibits the Activation of Hepatic Stellate Cells Induced by Acetaldehyde via Adenosine A2A Receptor Mediated by the cAMP/PKA/SRC/ERK1/2/P38 MAPK Signal Pathway. PLoS One. 9, e92482. doi:10.1371/ journal.pone.0092482

Wurm, A., Pannicke, T., Iandiev, I., Francke, M., Hollborn, M., Wiedemann, P., et al. (2011). Purinergic Signaling Involved in Müller Cell Function in the Mammalian Retina. Prog. Retin. Eye Res. 30, 324-342. doi:10.1016/ j.preteyeres.2011.06.001

Xu, K., Di Luca, D. G., Orrú, M., Xu, Y., Chen, J.-F., and Schwarzschild, M. A. (2016). Neuroprotection by Caffeine in the MPTP Model of Parkinson's Disease and its Dependence on Adenosine A2A Receptors. Neuroscience. 322, 129-137. doi:10.1016/j.neuroscience.2016.02.035

Zhao, M., Bai, Y., Xie, W., Shi, X., Li, F., Yang, F., et al. (2015). Interleukin-1 $\beta$ Level Is Increased in Vitreous of Patients with Neovascular Age-Related Macular Degeneration (nAMD) and Polypoidal Choroidal Vasculopathy (PCV). PLoS One. 10, e0125150. doi:10.1371/journal.pone.0125150

Zheng, S., Lin, Z., Liu, Z., Liu, Y., and Wu, W. (2018). Lipopolysaccharide Mediates the Destruction of Intercellular Tight junction Among Renal Tubular Epithelial Cells via RhoT1/SMAD-4/JAM-3 Pathway. Int. J. Med. Sci. 15, 595-602. doi:10.7150/ijms.23786

Zou, X. L., Wang, G. F., Li, D. D., Chen, J. X., Zhang, C. L., Yu, Y. Z., et al. (2018). Protection of Tight junction between RPE Cells with Tissue Factor Targeting Peptide. Int. J. Ophthalmol. 11 (10), 1594-1599. doi:10.18240/ijo.2018.10.04

Conflict of Interest: The authors declare that the research was conducted in the absence of any commercial or financial relationships that could be construed as a potential conflict of interest.

Publisher's Note: All claims expressed in this article are solely those of the authors and do not necessarily represent those of their affiliated organizations, or those of the publisher, the editors, and the reviewers. Any product that may be evaluated in this article, or claim that may be made by its manufacturer, is not guaranteed or endorsed by the publisher.

Copyright (c) 2022 Conti, Lazzara, Romano, Platania, Drago and Bucolo. This is an open-access article distributed under the terms of the Creative Commons Attribution License (CC BY). The use, distribution or reproduction in other forums is permitted, provided the original author(s) and the copyright owner(s) are credited and that the original publication in this journal is cited, in accordance with accepted academic practice. No use, distribution or reproduction is permitted which does not comply with these terms. 